\title{
Effects of Overnight Sleep Deprivation on Appetite and Physical Performance in Elite Female Soccer Players
}

\section{Seçkin Kadın Futbol Oyuncularında Gece Uykusu Yoksunluğunun Iștah ve Fiziksel Performans Üzerine Etkileri}

\author{
(D) Hamid Arazi, (D) Javad Mehrabani, (D) Mojdeh Irandoost, (D) Eisa Khaleghimamaghani \\ University of Guilan Faculty of Sport Sciences, Department of Exercise Physiology, Rasht, Iran
}

\begin{abstract}
Objective: Sleep and awakening are a biological cycle that is affected by physiological function, light and darkness, work programs, and other activities. The vital role of sleep in body function and appetite is essential, and this is especially important for athletes. Meanwhile, the conditions of soccer players are such that they are deprived of sleep, and this is a risk to a professional athlete. The aim of the current study was to examine the effects of overnight sleep deprivation on appetite and physical performance in elite female soccer players.

Materials and Methods: Twelve elite female soccer players in the premier league of Iran with 10-year history were selected to the study (age: $28.50 \pm 3.45 \mathrm{yr}$, height: $160.50 \pm 4.07 \mathrm{~cm}$, weight: $55.12 \pm 3.52 \mathrm{~kg}$, body mass index: $21.38 \pm 1.06 \mathrm{~kg} / \mathrm{m}^{2}$ ). Subjects were evaluated in two rounds with normal sleep and deprivation of night sleep (DNS) and between these two rounds was also a recovery week. The evaluations included physical performance and appetite.

Results: DNS had a significant effect on appetite (feeling hungry, full, satiate, and eating desire), reaction time, balance (static and dynamic), anaerobic power (peak power, minimum power, average power, and fatigue index), and aerobic performance ( $\mathrm{p} \leq 0.05)$.

Conclusion: DNS may induce disruptions on the appetite and physical performance of elite soccer players. For these, athletes should take into consideration adequate night sleep before performing physical tasks.

Keywords: Soccer players, sleep, circadian rhythm, appetite, performance
\end{abstract}

Öz

Amaç: Uyku ve uyanma; fizyolojik fonksiyonlardan, aydınlık ve karanlıktan, çalışma programlarından ve diğer etkinliklerden etkilenen biyolojik bir döngüdür. Vücut fonksiyonlarında ve iştahta uykunun hayati önemi vazgeçilmezdir ve bu özellikle sporcular için önemlidir. Bu arada, futbol oyuncularının şartları uykudan yoksun kalacakları şekildedir ve bu profesyonel bir sporcu için risktir. Bu çalışmada, seçkin kadın futbol oyuncularında gece uyku yoksunluğunun iştah ve fiziksel performans üzerindeki etkilerinin incelenmesi amaçlanmıştır.

Gereç ve Yöntem: Araştırmaya, Iran birinci liginde 10 yıllık geçmişi olan 12 seçkin kadın futbol oyuncusu seçildi (yaş: $28,50 \pm 3,45$ yıl, boy: $160,50 \pm 4,07 \mathrm{~cm}$, kilo: $55,12 \pm 3,52 \mathrm{~kg}$, beden kitle indeksi: $21,38 \pm 1,06$ $\mathrm{kg} / \mathrm{m}^{2}$ ). Denekler normal uyku ve gece uykusu yoksunluğu ile iki seansta değerlendirildi ve bu iki seans arasında bir iyileşme haftası da vardı. Değerlendirmelere fiziksel performans ve iştah dahil edildi.

Bulgular: Gece uykusu yoksunluğunun; iştah (acıkma, doyma, tokluk hissi ve yeme arzusu), reaksiyon süresi, denge (statik ve dinamik), anaerobik güç (tepe güç, minimum güç, ortalama güç ve yorgunluk indeksi) ve aerobik performans üzerinde önemli bir etkiye sahip olduğu gözlendi $(p \leq 0,05)$.

Sonuç: Gece uykusu yoksunluğu, seçkin futbol oyuncularının iştahı ve fiziksel performansı üzerinde bozulmalara neden olabilmektedir. Bundan dolayı, sporcular fiziksel görevlerine başlamadan önce yeterli gece uykusunu göz önünde bulundurmalıdırlar.

Anahtar Kelimeler: Futbol oyuncuları, uyku, sirkadiyen ritim, iştah, performans

\section{Introduction}

Sleep is one of the biological needs (1). Need to sleep among young adults (25-18 yr) and adults (26-64 yr) is suggested 7-9 hours (2-4), this time for athletes is $9-10$ hours (2) and more important than other people (5). Because the quality and quantity of sleep will be very effective on physical performance
$(6,7)$ and appetite $(8,9)$. While many reports have reported poor sleep quality among athletes $(3,5)$, this is a very worrying factor. The obvious reasons for sleep deprivation (SD) in athletes are jet lag, hotel beds, noise, stress, and anxiety before the competition and staying in the height, television interviews, doping tests, and unusual competition times $(2,3,10,11)$. SD

Address for Correspondence/Yazışma Adresi: Hamid Arazi PhD, University of Guilan Faculty of Sport Sciences, Department of Exercise Physiology, Rasht, Iran Phone: +98911 1399207 E-mail: hamidarazi@yahoo.com ORCID-ID: orcid.org/0000-0002-1594-6515 Received/Geliş Tarihi: 13.02.2019 Accepted/Kabul Tarihi: 03.06.2019

${ }^{\circ}$ Copyright 2018 by Turkish Sleep Medicine Society / Journal of Turkish Sleep Medicine published by Galenos Publishing House. 
will ultimately may lead to dysfunction in athletic performance and appetite.

In a study by Pallesen et al. (12) in 2017, it was found that soccer players skills were negatively affected by SD. In addition, Reilly et al. (13) measured the effects of SD on lift performance and concluded that SD could negatively affect performance. While sleep and appetite are in relationship, there is still a controversial between sleep and appetite relationship (14). However, Hibi et al. (9) in 2017 conducted a study to investigate the effects of low sleep on energy consumption, central body temperature and appetite, and observed that reducing sleep without affecting energy would increase appetite, which is indicative of calorie intake most of the time during a short sleep cycle, it increases the risk of overweight. In another study by Spiegel et al in 2004, SD was associated with lower levels of leptin, increased levels of ghrelin, and increased hunger and appetite (14).

In the meantime, there are always new strategies to resistance with the negative effects of $S D$, but more familiarity with these effects can have benefits for the review and offering of new strategies and methods to resistance with those effects. As noted, recent research has always looked at the effects of sleep with appetite and physical performance, and recent reports point out that the current conditions in professional football may lead to SD. For example, conditions such as stadium lighting conditions, display light in the stadium, as well as interactions and stimuli in the competition place may also affect the athlete's sleep (15). Therefore, in the present study, we seek to assess the effects of SD on physical performance and appetite in elite female soccer players, and our assumption is that SD likely will affect these two factors.

\section{Materials and Methods}

The subjects of this study were 12 elite female soccer players in the premier league of Iran with a history of 10 years (age: $28.50 \pm 3.45 \mathrm{yr}$, height: $160.50 \pm 4.07 \mathrm{~cm}$, weight: $55.12 \pm 3.52$ $\mathrm{kg}$, body mass index: $21.38 \pm 1.06 \mathrm{~kg} \cdot \mathrm{m}^{-2}$ ) and after applying the criteria for entering the test. Evaluation was done in three sessions. Session one: Familiarity with the research protocol, reporting oral and written consent of the subjects, completion of the health and physical activity questionnaire, and anthropometric measurements (Table 1). The second session consisted of SD, so that the subjects ate dinner at 9:00, then the SD was completed and at 8:00 am the appetite questionnaire (visual analogue scales) was completed by the subjects and then breakfast was consumed with 300-350 calories, finally, at $10 \mathrm{am}$ o'clock, evaluations of physical performance, including

\begin{tabular}{|l|l|}
\hline \multicolumn{2}{|l|}{ Table 1. Characteristics of participants $(\mathbf{n}=\mathbf{1 2})$} \\
\hline Variable & Mean \pm SD \\
\hline Age (year) & $28.50 \pm 3.45$ \\
\hline Height $(\mathrm{cm})$ & $160.50 \pm 4.07$ \\
\hline Body weight $(\mathrm{kg})$ & $55.12 \pm 3.52$ \\
\hline BMl $\left(\mathrm{kg} \cdot \mathrm{m}^{-2}\right)$ & $21.38 \pm 1.06$ \\
\hline BMl: Body mass index, SD: Standard deviation \\
\hline
\end{tabular}

reaction time and balance and anaerobic power and aerobic performance, were done. A 7-day course was considered for recovery and on the night of the $7^{\text {th }}$ day the subjects dined at 9 o'clock and slept at 11 o'clock. After 7:30, they woke up and completed the appetite questionnaire at 8 am and then ate breakfast with 300-350 calories. At 10 am o'clock, physical evaluations were repeated as a post-test (Figure 1).

It should be noted that the anaerobic power was measured with a RAST test and aerobic power with a test of 1609 meters or 1 mile. Also, the reaction time with software (reaction timer software) and the static balance with standing stork and dynamic balance were also evaluated by star testing and the protocol for this research project has been approved by the University Ethics Committee.

Normality of data was evaluated by Shapiro-Wilk test. To assess the difference between the two sessions with or without SD, Paired-Samples $t$ test was used at a significant level of $p<0.05$.

\section{Results}

\section{Appetite}

SD had a significant effect on appetite and significantly changed the feeling hungry, full, satiate and eating desire. The feeling hungry and eating desire were reduced with SD, but the feeling full and satiate increased significantly $(p \leq 0.05)$ (Figure 2$)$.

\section{Reaction Time}

SD had a significant effect on the RT and the RT increased with SD $(p \leq 0.05)$ (Table 2).

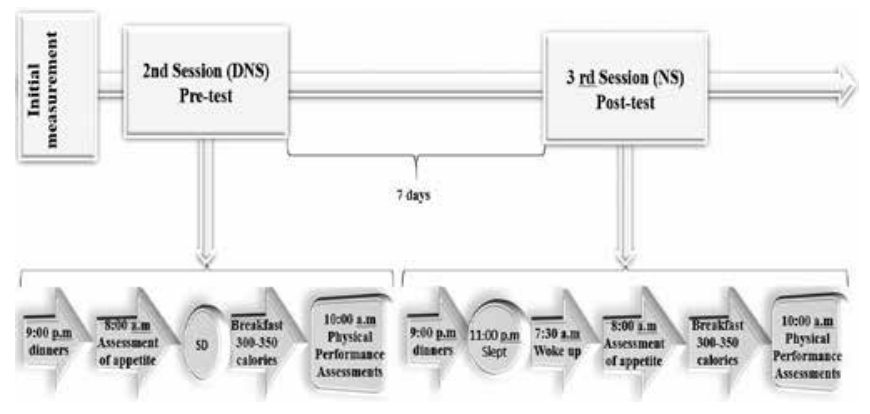

Figure 1. The design of the study protocol

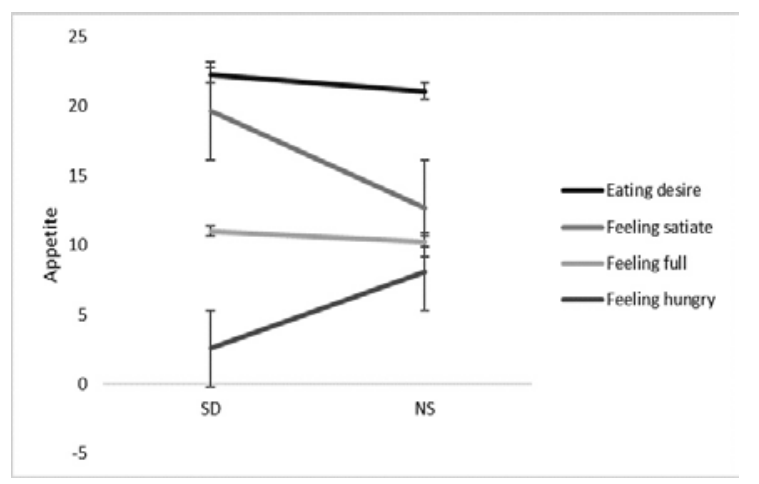

Figure 2. Sleep deprivation effects on appetite (mean \pm SE) 
Arazi et al.

Sleep Deprivation on Appetite and Performance

\begin{tabular}{|c|c|c|c|}
\hline & & Condition & Mean \pm SD \\
\hline \multirow{2}{*}{\multicolumn{2}{|c|}{ RT (s) }} & SD & $5.94 \pm 0.39$ \\
\hline & & NS & $5.33 \pm 0.34^{*}$ \\
\hline \multirow{2}{*}{\multicolumn{2}{|c|}{ Aerobic performance (min) }} & SD & $10.19 \pm 0.72$ \\
\hline & & NS & $8.28 \pm 0.74^{*}$ \\
\hline \multirow{4}{*}{ 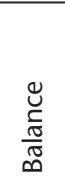 } & \multirow{2}{*}{ Static (s) } & SD & $16.85 \pm 3.29$ \\
\hline & & NS & $25.49 \pm 6.07^{*}$ \\
\hline & \multirow{2}{*}{ Dynamic (cm) } & SD & $131.11 \pm 9.53$ \\
\hline & & NS & $134.99 \pm 9.56^{*}$ \\
\hline \multirow{8}{*}{ 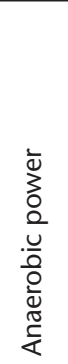 } & \multirow{2}{*}{$\mathrm{PP}(\mathrm{w})$} & SD & $324.28 \pm 78.83$ \\
\hline & & NS & $590.96 \pm 132.92^{*}$ \\
\hline & \multirow{2}{*}{$\mathrm{MP}(\mathrm{w})$} & SD & $158.27 \pm 20.00$ \\
\hline & & NS & $259.97 \pm 48.16^{*}$ \\
\hline & \multirow{2}{*}{$\mathrm{AP}(w)$} & SD & $6.77 \pm 0.29$ \\
\hline & & NS & $5.68 \pm 0.26^{*}$ \\
\hline & \multirow{2}{*}{$\mathrm{FI}$} & SD & $4.15 \pm 1.88$ \\
\hline & & NS & $9.82 \pm 3.55^{*}$ \\
\hline
\end{tabular}

\section{Balance}

There were significant changes in static and dynamic balance with SD and the balance was negatively affected by SD $(\mathrm{p} \leq 0.05)$ (Table 2).

\section{Anaerobic Power}

SD had a significant effect on anaerobic power (PP, MP, AP and $\mathrm{FI})$. So that the PP, MP, and FI decreased with SD, but the AP increased significantly ( $\mathrm{p} \leq 0.05)$ (Table 2$)$.

\section{Aerobic Performance}

Significant changes were observed between the pre-test and post-test. the aerobic performance was negatively affected by SD $(p \leq 0.05)$ (Table 2$)$.

\section{Discussion}

SD is a common problem in advanced societies, which has an irreparable consequence for athletes and may affects the appetite and performance of athletes from different aspects. Which is among the athletes of football, having certain conditions more affected by this problem. In the present study, we sought to investigate the effects of SD on athletic performance and appetite in elite female soccer players. Although we did not an assertion, our measurements showed that SD can affect the athletic performance and appetite of elite soccer players.

The appetite in our study was affected by SD. Several reports also indicate that low sleep is associated with an increase in body mass index (16), and in the present study, we observed that feeling hungry and eating desire reduced with SD. This finding contrasts with most of the results of previous studies, and studies have seen increased levels of ghrelin and increased hunger with falling sleep $(14,17,18)$. The reason for this contradiction can be related to melatonin, as the melatonin hormone is affected by watching television, and watching TV will lower the secretion of the hormone (19), which lowering the secretion of this hormone can be a factor in reducing hunger (20). However, the lack of measurement of the melatonin hormone is one of the major constraints of the present study, which in future researchers are eager to examine this hormone. The RT is consistent with most of the past research and was increased with SD. And this is not unexpected, because SD is one of the main causes of injury on psychological and temperamental factor (21). The front lobe of the brain responds quickly to sleep, and this lobe is also sensitive to psychological acts $(22,23)$. In addition, the effects of fatigue due to SD and loss of sleep paradoxical is also important but it seems that fatigue was not very effective in comparison with the loss of paradoxical sleep, because in our study, SD is acute and fatigue is noticeable in the deprived of long-term sleep (24).

SD in our research negatively affected the static and dynamic balance. This negative effect has been observed in other studies with long periods of SD, which was not the case in our research, and the main reason for the contradiction could be the processing speed of visual inputs that decreases by SD overnight and affects postural control. However, the study of the effects of SD at different time intervals can be an attractive research topic for future researchers.

The anaerobic performance is impaired by SD, especially in the long-term SD (25). one of the major disruptions to SD is fatigue (26). And fatigue has a negative effect on aerobic performance. Since anaerobic performance is related to aerobic performance (27), it is expected that the anaerobic function is impaired by a damaged in aerobic function.

In this regard, Martin reported that 36 hours of SD reduced physical performance and decreased time to exhaustion with long-distance while walking on the treadmill with $80 \%$ of $\mathrm{VO}_{2} \max (28)$.

On the other hand, Azboy and Kaygisiz (29) also concluded that 30 hours of SD reduced exercise activity with reduced ventilation time and fatigue. They also concluded that SD has a more negative effect on fast and power activities and this is due to the features of these activities. so that athlete must be implemented within a limited time and with maximum capacity. These activities are impaired by SD, and this disorder results in SD due to the lack of energy release (29).

The effect of time-day on the properties of muscle contraction is also very important, so that the time-day is influenced by intracellular changes such as inorganic phosphate or the effect of a circadian rhythm at a central temperature that can subsequently affect on calcium release by the sarcoplasmic reticulum and ultimately affect performance (30). Therefore, the lack of temperature control is also the limitations of the present study for precise conclusions. Future researchers should control this issue with the assessment of the effects of SD at different times of the day. 


\section{Conclusions}

SD affects the physical performance and appetites of elite female soccer players. As a result, coaches should seek strategies to combat SD and modulate their effects. In the future researches, it is suggested to examine the effects of SD in different time periods in various sports disciplines and with other variables.

\section{Acknowledgements}

The authors would like to thank the participants for their dedication and effort throughout the study.

\section{Ethics}

Ethics Committee Approval: It was taken by Ethics Committee of University.

Informed Consent: Informed consent statement was in adherence with the human subject's guidelines of Research Center.

Peer-review: Internally peer-reviewed.

\section{Authorship Contributions}

Concept: H.A., J.M., Design: H.A., Data Collection or Processing: M.I., Analysis or Interpretation: M.I., Literature Search: E.K., Writing: H.A., J.M. E.K.

Conflict of Interest: No conflict of interest was stated by the authors.

Financial Disclosure: The authors declared that this study received no financial support.

\section{References}

1. Lima PF, Medeiros A, Araujo J. Sleep-wake pattern of medical students: early versus late class starting time. Braz J Med Biol Res 2002;35:1373-7.

2. Bonnar D, Bartel K, Kakoschke N, Lang C. Sleep interventions designed to improve athletic performance and recovery: a systematic review of current approaches. Sports Med 2018;48:683-703.

3. Kölling S, Duffield R, Erlacher D, Venter R, Halson SL. Sleep-related Issues for Recovery and Performance in Athletes. Int J Sports Physiol Perform 2019;14:144-8.

4. Fullagar HH, Duffield R, Skorski S, Coutts AJ, Julian R, Meyer T. Sleep and recovery in team sport: current sleep-related issues facing professional team-sport athletes. Int J Sports physiol Perform 2015;10:950-7.

5. Hoshikawa M, Uchida S, Hirano Y. A Subjective Assessment of the Prevalence and Factors Associated with Poor Sleep Quality Amongst Elite Japanese Athletes. Sports Med Open 2018;4:10.

6. Fullagar HH, Skorski S, Duffield R, Hammes D, Coutts AJ, Meyer T. Sleep and athletic performance: the effects of sleep loss on exercise performance, and physiological and cognitive responses to exercise. Sports Med 2015;45:161-86.

7. Massar SAA, Lim J, Sasmita K, Chee MWL. Sleep deprivation increases the costs of attentional effort: performance, preference and pupil size. Neuropsychologia 2019;123:169-77.

8. Cooper CB, Neufeld EV, Dolezal BA, Martin JL. Sleep deprivation and obesity in adults: a brief narrative review. BMJ Open Sport Exerc Med 2018;4:e000392.

9. Hibi M, Kubota C, Mizuno T, Aritake S, Mitsui Y, Katashima M, Uchida S. Effect of shortened sleep on energy expenditure, core body temperature, and appetite: a human randomised crossover trial. Sci Rep 2017;7:39640.
10. Rosa JPP, Silva A, Rodrigues DF, Simim MA, Narciso FV, Tufik S, Bichara JJ, Pereira SRD, Da Silva SC, de Mello MT. Effect of bright light therapy on delayed sleep/wake cycle and reaction time of athletes participating in the Rio 2016 Olympic Games. Chronobiol Int 2018;35:1095-103.

11. Whitworth-Turner C, Di Michele R, Muir I, Gregson W, Drust B. A comparison of sleep patterns in youth soccer players and nonathletes. Science and Medicine in Football 2018;2:3-8.

12. Pallesen S, Gundersen HS, Kristoffersen M, Bjorvatn B, Thun E, Harris A. The effects of sleep deprivation on soccer skills. Percept Mot Skills 2017;124:812-29.

13. Reilly T, Piercy M. The effect of partial sleep deprivation on weightlifting performance. Ergonomics 1994;37:107-15.

14. Spiegel K, Tasali E, Penev P, Van Cauter E. Brief communication: sleep curtailment in healthy young men is associated with decreased leptin levels, elevated ghrelin levels, and increased hunger and appetite. Ann Intern Med 2004;141:846-50.

15. Nédélec M, Halson S, Abaidia AE, Ahmaidi S, Dupont G. Stress, sleep and recovery in elite soccer: a critical review of the literature. Sports Med 2015;45:1387-400.

16. Taheri S, Lin L, Austin D, Young T, Mignot E. Short sleep duration is associated with reduced leptin, elevated ghrelin, and increased body mass index. PLoS Med 2004;1:62.

17. Schmid SM, Hallschmid M, JAUCH CHARA K, Born J, Schultes B. A single night of sleep deprivation increases ghrelin levels and feelings of hunger in normal weight healthy men. J Sleep Res 2008;17:331-4.

18. Brondel L, Romer MA, Nougues PM, Touyarou P, Davenne D. Acute partial sleep deprivation increases food intake in healthy men. Am J Clin Nutr 2010;91:1550-9.

19. Figueiro MG, Wood B, Plitnick B, Rea MS. The impact of watching television on evening melatonin levels. Journal of the Society for Information Display 2013;21:417-21.

20. Piccinetti CC, Migliarini B, Olivotto I, Coletti G, Amici A, Carnevali O. Appetite regulation: the central role of melatonin in Danio rerio. Horm Behav 2010;58:780-5.

21. Davenne D. Sleep of athletes-problems and possible solutions. Biological Rhythm Research 2009;40:45-52.

22. Taheri M, Arabameri E. The effect of sleep deprivation on choice reaction time and anaerobic power of college student athletes. Asian J Sports Med 2012;3:15-20.

23. Jones $\mathrm{K}$, Harrison Y. Frontal lobe function, sleep loss and fragmented sleep. Sleep Med Rev 2001;5:463-75.

24. Jarraya $m$, Jarraya $S$, Chtourou $H$, Souissi N. Effect of time of day and partial sleep deprivation on the reaction time and the attentional capacities of the handball goalkeeper. Biological Rhythm Research 2014;45:183-91.

25. Souissi N, Sesboüé B, Gauthier A, Larue J, Davenne D. Effects of one night's sleep deprivation on anaerobic performance the following day. Eur J Appl Physiol 2003;89:359-66.

26. Myles WS. Sleep deprivation, physical fatigue, and the perception of exercise intensity. Med Sci Sports Exerc 1985;17:580-4.

27. Gillen ZM, Wyatt FB, Winchester JB, Smith DA, Ghetia V. The Relationship Between Aerobic and Anaerobic Performance in Recreational Runners. Int J Exerc Sci 2016;9:625-34.

28. Martin BJ. Effect of sleep deprivation on tolerance of prolonged exercise. Eur J Appl Physiol 1981;47(4):345-54.

29. Azboy O, Kaygisiz Z. Effects of sleep deprivation on cardiorespiratory functions of the runners and volleyball players during rest and exercise. Acta Physiol Hung 2009;96:29-36.

30. Souissi N, Souissi M, Souissi H, Chamari K, Tabka Z, Dogui M, Davenne D. Effect of time of day and partial sleep deprivation on short term, high power output. Chronobiol Int 2008;25:1062-76. 